\title{
TECHNICAL ASPECTS OF USING THE HEAT PUMP AT THE SHIP
}

\section{Sylwester Trzebiński ${ }^{\circledR}$}

1st Military Centre of Metrology, Władysława Miegonia 45 Str., 81-103 Gdynia, Poland; e-mail: sylwek-t@wp.pl; ORCID ID 0000-0002-3111-3097

\begin{abstract}
The paper attempts to analyze the technical possibilities of using a compressor heat pump to recover waste heat from energy processes implemented by a watercraft. The amount of waste heat that could be used for the heating needs of the vessel was estimated and the hydrothermal potential of the marine waters was assessed. The possibilities of reducing the power of the ship's power plant used to power the ship's heating installation were determined.
\end{abstract}

Key words:

heat pump, waste heat, hydrothermal heat, ship heating installation.

Research article

(C) 2019 Sylwester Trzebiński This is an open access article licensed under the Creative Commons Attribution-NonCommercial-NoDerivatives 4.0 license (http://creativecommons.org/licenses/by-nc-nd/4.0/) 


\section{INTRODUCTION}

A vessel, regardless of whether it is a ship, a merchant ship or a passenger ferry, is in a sense a 'connection' of a residential object and a vehicle with an internal combustion engine. Contemporary residential buildings in modern construction are characterized by very low energy demand for both heating and cooling. Providing thermal comfort is realized on the one hand through advanced technical solutions for building air conditioning based, among others for heat pumps on the other hand, high thermal insulation of the building. Each modern building has additionally mechanical ventilation with heat recovery.

Modern marine climate installations are still based largely on electric heaters and air-conditioning units in which the heating is carried out electrically and cooling using a freon cooling system. Steam boilers and steam heating installations are used less frequently and will probably soon be a relic of the past rather than subject to technical development.

Extensive air conditioning installations significantly burden ship power plants both in summer and in winter. In addition, there is a constant tendency to increase the social and living comfort of the ship's or passengers' crew, resulting in an increase in both the heating power and, above all, the cooling power [7]. It is technically impossible to improve the insulating parameters of a ship due to thermal modernization. The search for new solutions based on available technology in the field of ventilation and air conditioning, as well as proven in other areas such as land construction seems justified. An additional element that encourages the use of a heat pump on the ship is the fact of producing significant amounts of waste heat from technological processes taking place in a marine engine or power plant.

Heat engines should be cooled constantly, which causes the production of significant amounts of 'hot' water ejected into the sea. The utilization of waste energy to reduce electricity consumption is particularly desirable when operating in the sea where it is extremely valuable and has until recently been used almost exclusively for purposes more important than heating and cooling.

The power of modern air conditioning installations of MW RP ships makes up about 20\% [4] of the power of the ship's power plant. Air handling units of vessels are, therefore, an area of the ship's energy balance which is most suitable for limiting the consumption of electricity with the participation of renewable energy.

The aim of the paper is to present the use of a heat pump in an air-conditioning installation of a vessel as a new approach to the issue of the use of renewable hydrothermal and waste energy aimed at reducing the consumption of primary fuels. 


\section{HEAT PUMP AS A COMPONENT OF THE SHIP AIR CONDITIONING}

A heat pump is a thermal machine forcing heat to flow from a lower temperature area to an area with a higher temperature. This process goes against the natural direction of heat transfer and takes place thanks to external mechanical energy (in compressor heat pumps) or thermal energy (in absorption pumps) [6]. The first heat pumps were constructed over one hundred years ago and the first one in Europe was established in Switzerland in 1938 and continues to this day [6]. Currently, the most commonly used in the production process of heat pumps is the left-side steam circuit, identical to the refrigerator circuit but carried out in a different temperature range. The installation of a compressor heat pump, which is characterized by the highest heating capacity among such devices available on the market, is created (fig. 1):

- lower heat source $T_{C}$;

- compressor heat pump (work supplied $W$ );

- upper heat source $T_{H}$.

a)

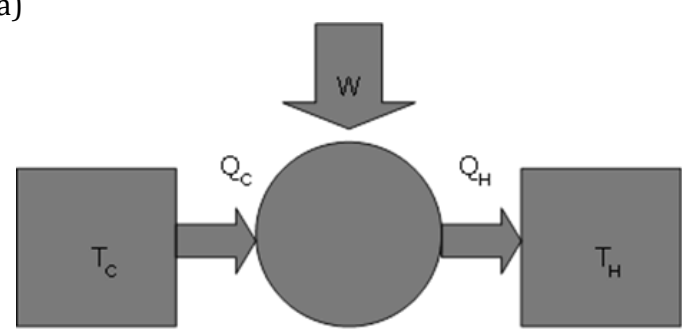

b)

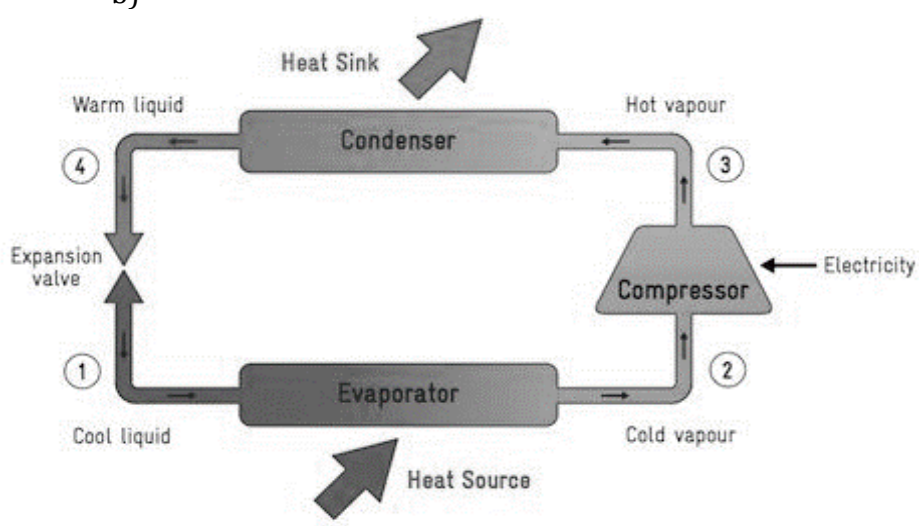

Fig. 1. General principle of operation of a heat pump installation [8]:

a) $W$ - work supplied, $T_{C}$ - temperature of the lower source, $T_{H}-$ temperature of the upper source; $Q_{C}$ - low temperature energy, $Q_{H}-$ high temperature energy;

b) main scheme of the heat pump installation 
Together with the technical development and the necessity resulting from the EU Communications and Directives [3], investing in renewable energy sources has increased the interest in heat pumps. In addition, the possibility of using heat pumps is influenced by their high reliability and durability as well as the ability to control and automate air-conditioning systems. Currently used installations with heat pumps usually serve simultaneously for heating and cooling purposes, whereby the cooling can be implemented as passive without the use of a compressor (circulation pumps use as the refrigerant the bottom source in the form of 'ice' water) or active. The combination of both heating and cooling functions in one device also has a positive effect on the possibility of reducing large amounts of installation devices (compressors, pumps, exchangers, electric motors) and simplifying design solutions when balancing heat losses. Due to the type of low and high temperature heat carrier, the following heat pump systems are distinguished [6]: water - water $(\mathrm{W} / \mathrm{W})$, water - $\operatorname{air}(\mathrm{W} / \mathrm{A})$, $\operatorname{air}-\operatorname{water}(\mathrm{A} / \mathrm{W})$, $\operatorname{air}-\operatorname{air}(\mathrm{A} / \mathrm{A})$.

\section{POTENTIAL WASTE WARM RECOVERY AREAS}

A vessel is an area with a significant saturation of mechanical equipment that generates, processes and uses electrical and mechanical energy. These processes are always accompanied by the generation of heat that is collected by means of cooling water or cooling air. The element that is indispensably connected with the functioning of the crew is also the need to produce hot utility water needed for living purposes as well as production and storage of sewage. Guided by the above, potential ship installations have been established that can be used for heat recovery processes using air-conditioning systems based on heat pumps:

- water installation for cooling main engines;

- water installation of cooling propulsion engines in a ship's power plant;

- cooling water cooling installation;

- installation of marine engine room ventilation;

- installation of ventilation of ship rooms (e.g. naval kitchen, social rooms);

- sewage installation and tanks.

The water has a high specific heat of $c_{p}=4190 \mathrm{~J} /(\mathrm{kg} \cdot \mathrm{K})[5]$ and it is much higher than the specific heat of air $c_{p}=1000 \mathrm{~J} /(\mathrm{kg} \cdot \mathrm{K})$ [5]. Among other things, for this reason water seems to be a better factor to use in the recovery of waste heat. In addition, when comparing the amount of heat discharged resulting from the mass 
stream and temperature, it seems that the best place for heat recovery on the ship is the cooling system for the main engines and the ship's power plant. Based on estimated calculations resulting from the assumed flows (similar to the efficiency of circulation pumps on the ship) and temperatures, it is possible to determine the thermal power required to heat the ship's premises, such as a rocket cutter. By adopting the initial temperature of the cooling water, the engines at $20^{\circ} \mathrm{C}$ and the water mass flow at the level of three tons per hour can obtain thermal power during the operations of the naval ship at the level of $42 \mathrm{~kW}$ [2]. Using a useful tool in the form of an energy calculator, you can easily estimate the heating power of the assumed flow and the temperature of the initial and final cooling water mass flow. Depending on the load of the power plant or ship's power plant, cooling water parameters may have different values than those assumed but their lower values in the scope of changes have been assumed. It can be noticed that even at low values of assumed temperatures and low flow, obtaining the required thermal power value is not difficult to achieve (fig. 2).

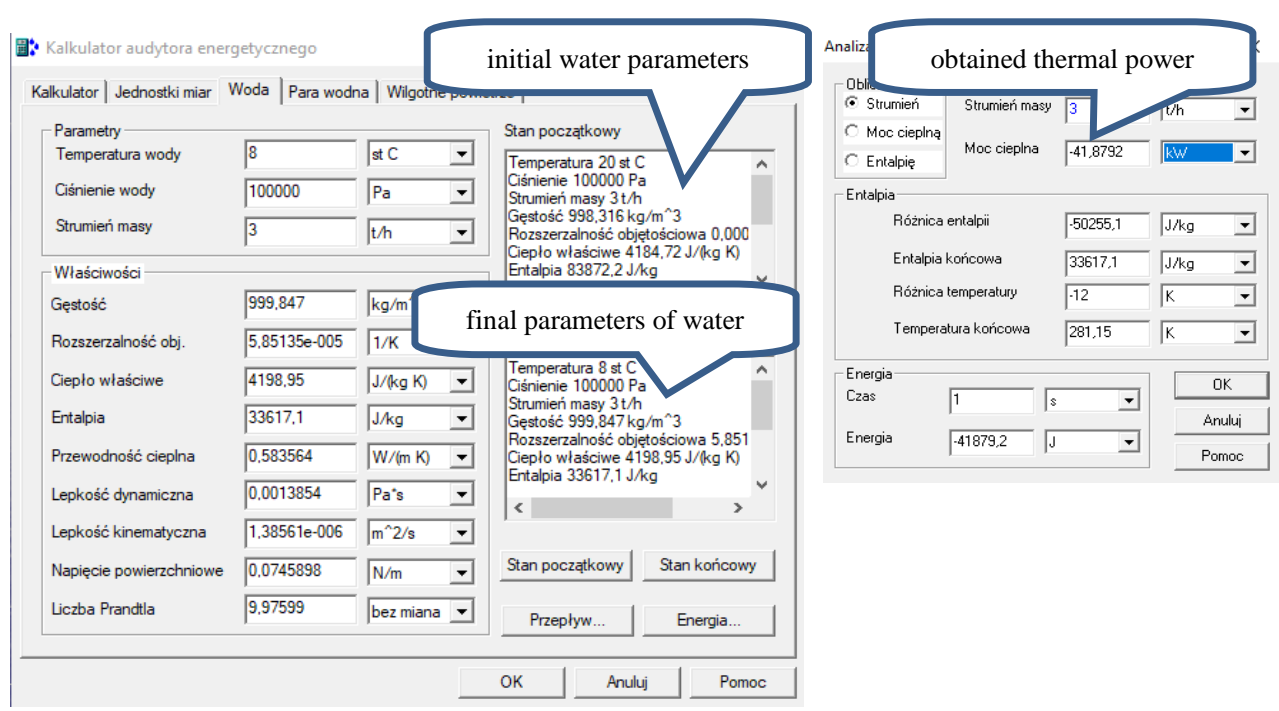

Fig. 2. Estimated calculation of waste energy for assumed temperatures and flow of engine cooling water for the vessel

\section{ENERGY BALANCE OF COVERS BASED ON THE EXAMPLE OF THE MISSILE SHIP}

The ship's energy balance shows that the power of heating receivers installed on a ship, such as a rocket cutter, is $132.5 \mathrm{~kW}$ [2]. 
It is the total heating power of electric heaters installed in the engine room, ship's rooms as well as water heaters, main engines, lubricating oil heaters and fresh water heaters for household purposes (tab. 1). The total power of the ship's heating system also consists of electric drive motors for circulation pumps for the main engines and lubricating oil heating systems not included in the list.

Tab. 1. List of heating devices from the energy balance of a missile ship [2]

\begin{tabular}{|c|c|c|c|}
\hline \multirow{2}{*}{ Receipt name } & \multicolumn{3}{|c|}{ Receive parameters installed } \\
\cline { 2 - 4 } & $\begin{array}{c}\text { Quantity receivers } \\
{[\mathrm{pcs}]}\end{array}$ & $\begin{array}{c}\text { The power } \\
\text { of the receiver } \\
{[\mathrm{kW}]}\end{array}$ & $\begin{array}{c}\text { Total charged power } \\
{[\mathrm{kW}]}\end{array}$ \\
\hline Space heating & 1 & 43.1 & 43.1 \\
\hline Heating of the power plant & 2 & 13.2 & 26.4 \\
\hline SG cooling water heater & 3 & 15 & 45 \\
\hline Fresh water heater & 3 & 3 & 9 \\
\hline $\begin{array}{c}\text { Heaters of the SG oil } \\
\text { circulation tank }\end{array}$ & 3 & 3 & $\mathbf{1 3 2 . 5}$ \\
\hline Sum & - & - & 9 \\
\hline
\end{tabular}

During operation in the sea, the ship uses only space heating receivers and fresh water heaters that have been designed for the designed load factors at the level of around $41 \mathrm{~kW}$ (tab. 2).

Tab. 2. List of heating devices from the energy balance of a missile ship during sea operations [2]

\begin{tabular}{|c|c|c|c|}
\hline \multirow{2}{*}{ Receipt name } & \multicolumn{3}{|c|}{ Receive parameters installed } \\
\cline { 2 - 4 } & $\begin{array}{c}\text { Quantity receivers } \\
{[\mathrm{pcs}]}\end{array}$ & $\begin{array}{c}\text { The power } \\
\text { of the receiver } \\
{[\mathrm{kW}]}\end{array}$ & $\begin{array}{c}\text { Total charged power } \\
{[\mathrm{kW}]}\end{array}$ \\
\hline $\begin{array}{c}\text { Space heating } \\
\text { Heating of the power } \\
\text { plant }\end{array}$ & 0.8 & 43.1 & 34.4 \\
\hline SG cooling water heater & - & 26,4 & - \\
\hline Fresh water heater & 0.7 & 45 & 6.3 \\
\hline $\begin{array}{c}\text { Heaters of the SG oil } \\
\text { circulation tank }\end{array}$ & - & 9 & - \\
\hline Sum & - & - & $\mathbf{4 0 . 7}$ \\
\hline
\end{tabular}

When estimating the thermal power of the cooling waste water from the main engines of the vessel, it is possible to determine the technical parameters of the compressor heat pump installed on the ship could realize heat recovery and use them for heating purposes while minimizing the load on the ship's power plant. 
Using the software available on the market for the selection of installation devices, such as the NIBE VPDim 2.4.4 program, you can determine the heat pump of a given type for the estimated required level of heating power.

The technical parameters of the heat pump used in marine air conditioning as a result of the selection allow to state that the heat pump F1330 [9] with a capacity of $40 \mathrm{~kW}$ should cover the entire heat demand on the ship during sea operations. At the same time, using waste heat coming from the cooling of main engines and power plants it is able to perform the heating function with a high average coefficient of heating efficiency COP [6] (Coefficient of Performance) at COP $=4.9$. This coefficient uniquely characterizes the possibilities of reducing the load on the ship's power plant during sea operations:

$$
C O P=\frac{\text { heating power of the heat pump }}{\text { the electricity power consumed from the grid }} .
$$

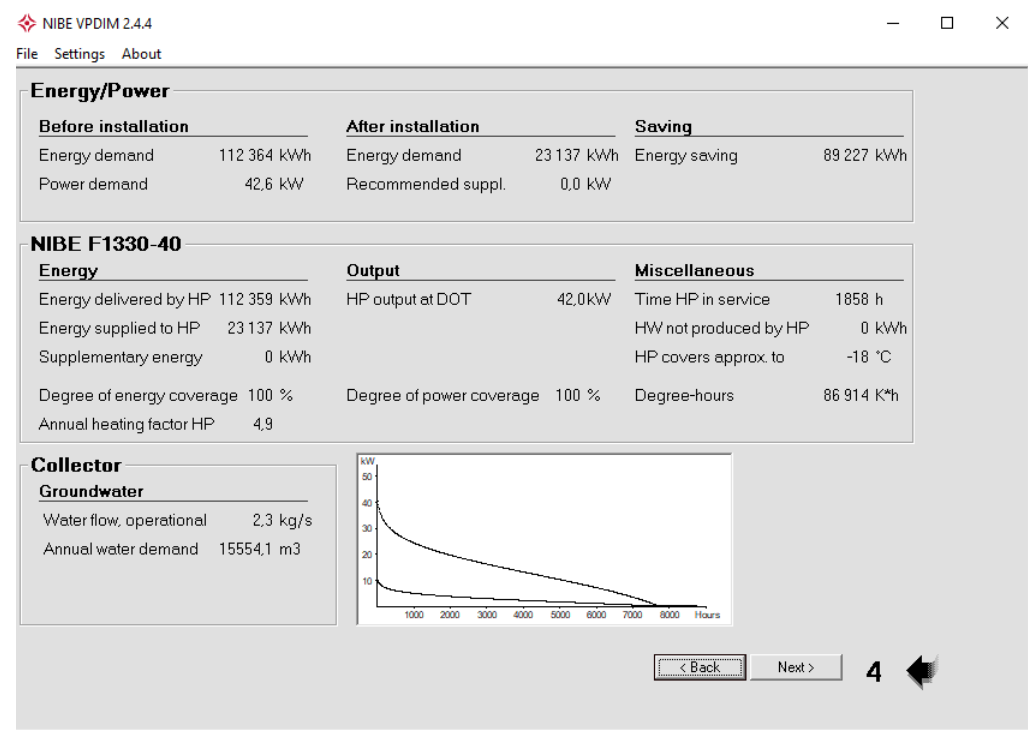

Fig. 3. The choice of the heat pump to the required level of heating power demand using waste water as the bottom source [9]

The air-conditioning system with a heat pump can also use the hydrothermal energy of seawater as the bottom source. Sea water from the point of view of the ship is common and relatively easy to obtain. It has a high specific heat and a freezing point below zero. Its biggest drawback is its incoherent or the lowest temperature occurs in the period of the highest demand for thermal energy. The vertical temperature distribution for the Baltic Sea for the winter season is shown in fig. 4 . 


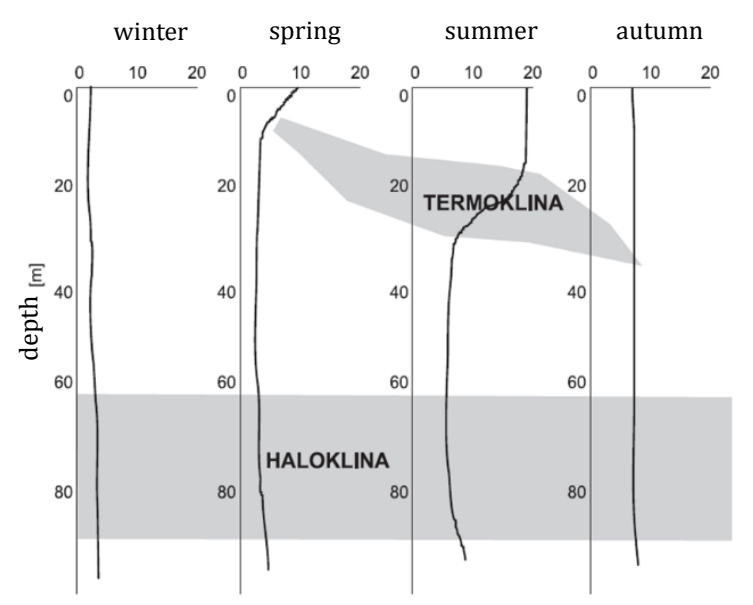

Fig. 4. Seasonal variability of seawater temperature distribution [1]

For analogous assumptions, it is possible to determine the appropriateness of using heat well with the lower source as sea water for waste heat. Due to the much lower temperature parameters and the risk of freezing below $0{ }^{\circ} \mathrm{C}$, in this case the necessary flows of the outboard mass stream will be much higher. However, the energy effect of such a solution in the case of success will be significantly greater. The total installed power for generating thermal energy on the ship is $132 \mathrm{~kW}$ [2]. Taking into account the coefficients of simultaneity and load designed in the energy balance, they give the total required electrical power of $101.7 \mathrm{~kW}$ [2]. Comparing the heating power needed to heat an average ship size of $101.7 \mathrm{~kW}$ to a medium sized residential building with an area of $150 \mathrm{~m}^{2}(7-10) \mathrm{kW}$ (depending on the energy class of the building), we can easily see the disproportion in the necessary energy expenditure as well as financial.

Assuming, as before, the minimum value of the water temperature in this case, the outboard level of $4{ }^{\circ} \mathrm{C}$ and the required heating power of about $132 \mathrm{~kW}$, it is possible to determine the required stream of water weight around $30 \mathrm{t} / \mathrm{h}$ (fig. 5).

It is worth noting that the heating installation with the bottom source in the form of sea water is able to perform heating functions on the ship with the continuously high average COP heating rate at the level of 4.0. Such a high COP results from the fact that during the heating period, the lowest temperature of sea water at the temperature level of about $3{ }^{\circ} \mathrm{C}$ is maintained to a maximum of one month a year throughout the heating period and in our latitude is usually higher. In addition, standard heat pumps used in industry have the ability to combine in cascades and the ability to modulate the switched heating power according to the demand 
resulting from the gradient of external temperature changes. The NIBE F1330 [9] heat pump used in the simulation of use in a marine air conditioning system has the ability to connect up to 9 units with a total capacity of $540 \mathrm{~kW}$.

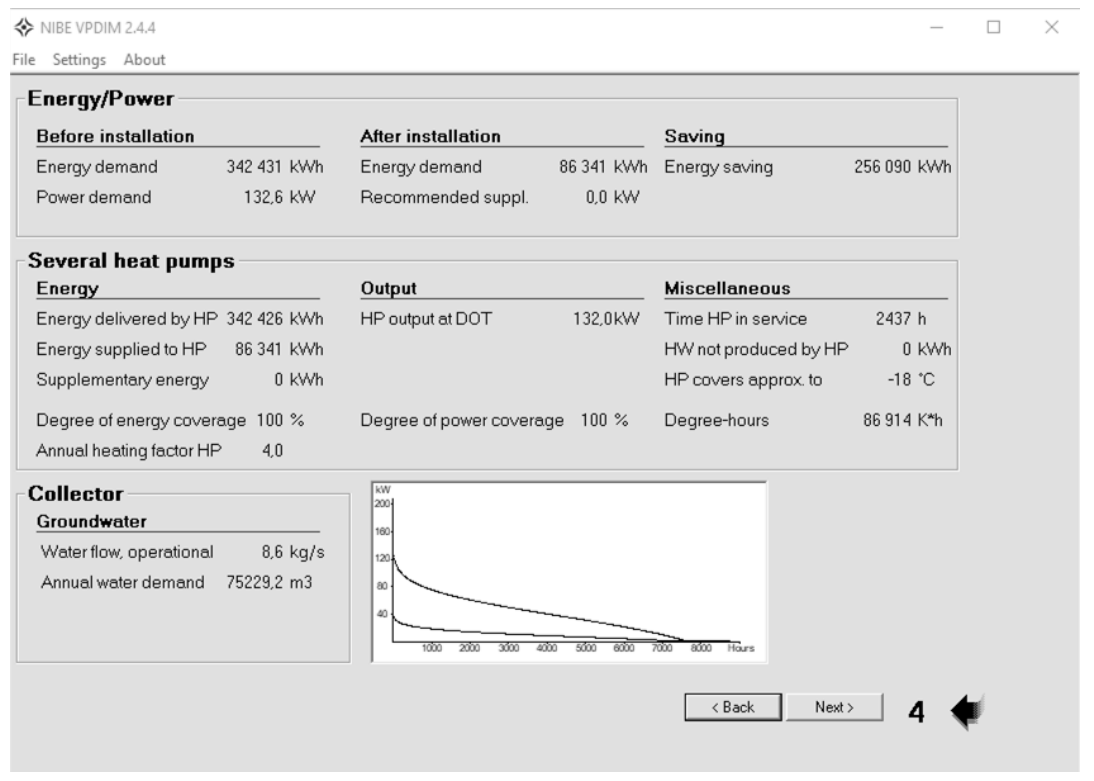

Fig. 5. Selection of the heat pump to the required level of heating power demand using the outboard water as the bottom source [9]

Considering the use of a heat pump compressor in the ship's heating installation as a result of the estimated simulations, it can be concluded that there is a reasonable possibility of reducing the power of the ship's power plant during sea operations. Additionally, it is possible to reduce the required electric power supplied from the shore station in the event of a ship stopping at the port.

In the case of waste water and activities at sea (1), in the case of a stoppage in port and sea water (2):

$$
\begin{aligned}
& \text { the required power of electricity in the sea }=\frac{\text { required heating power in the sea }}{4,9} \\
& \text { required electricity from land }=\frac{\text { required heating power in the port }}{4,0}
\end{aligned}
$$

The calculations presented in the study were made on the basis of commercial software with many simplifying assumptions used to design heating installations based on heat pumps in civil engineering. The calculations are estimates and can only serve the new possibilities and directions of development of ship heating installations. 


\section{CONCLUSIONS}

Climate changes related to greenhouse gas emissions as well as the dynamic development of air-conditioning technology determines the necessity but also the possibility of searching for new solutions for ship conditioning systems. Space heating and domestic hot water preparation using electricity is currently the most expensive among the solutions available on the market, however, in the case of the most widespread vessels. Extracting heat from low-temperature renewable sources is technologically feasible and reasonable from the point of view of the ship's operation. The amount of waste heat resulting from the ship's operation is significant and can be partially recovered using a heat pump. The use of a heat pump on MW RP vessels can significantly reduce the power of a ship's power plant during operations at sea and significantly reduce the amount of electricity consumed during a stay in a port.

\section{REFERENCES}

[1] Andrulewicz E., Szymelfenig M., Urbański J., Morze Bałtyckie - o tym warto wiedzieć, 'Zeszyty Zielone Akademii", 1998, No. 7, Publ. Polski Klub Ekologiczny [Baltic Sea - it is worth knowing about it - available in Polish].

[2] Bilans energetyczny okrętu. 660M-DZ-601-60-01, Publ. Stocznia Marynarki Wojennej, [Energy balance of the ship - available in Polish].

[3] Komunikat Komisji do Parlamentu Europejskiego, Rady, Europejskiego Komitetu Ekonomiczno-Społecznego i Komitetu Regionów. Plan na rzecz efektywności energetycznej z 2011 [Communication from the Commission to the European Parliament, the Council, the European Economic and Social Committee and the Committee of the Regions. An Energy Efficiency Plan 2011 available in Polish].

[4] Pojawa B., Trzebiński S., Symulacja efektywności wykorzystania pompy ciepła w okrętowych instalacjach klimatyzacyjnych, 'Postępy Nauki i Techniki', 2012, No. 15, pp. 134-144 [Simulation of efficiency of utilization of the heat pump in the ship air-conditioning system - available in Polish].

[5] Pudlik W., Termodynamika, Gdańsk 1998 [Thermodynamics — available in Polish].

[6] Rubik M., Pompy ciepła w systemach geotermii niskotemperaturowej, Publ. Oficyna Wydawnicza Multico, Warszawa 2011 [Heat pumps in low temperature geothermal systems - available in Polish].

[7] IV Forum Efektywności Energetycznej 'Globalne trendy w optymalizacji energooszczędnych rozwiązań w transporcie', Warszawa 2012 [4th Energy Efficiency Forum 'Global Trends in the Optimization of Energy-Saving Solutions in Transport — available in Polish]. 
[8] BS Drabner GmbH, [online], https://ex82.bs-drabner.de/diagram-heat-pump-system.html [access 12.01.2019].

[9] NIBE Biawar, [online], https://www.biawar.com.pl/ [access 12.01.2019].

\section{TECHNICZNE ASPEKTY ZASTOSOWANIA POMPY CIEPLA NA OKRĘCIE}

\section{STRESZCZENIE}

W artykule podjęto próbę analizy technicznych możliwości wykorzystania sprężarkowej pompy ciepła do odzysku ciepła odpadowego pochodzącego z procesów energetycznych realizowanych przez jednostkę pływającą. Oszacowano ilości ciepła odpadowego możliwego do wykorzystania dla potrzeb grzewczych jednostki pływającej oraz oceniono potencjał hydrotermiczny wód morskich. Określono możliwości redukcji mocy elektrowni okrętowej wykorzystywanej do zasilania instalacji grzewczej okrętu.

Słowa kluczowe:

pompa ciepła, ciepło odpadowe, ciepło hydrotermiczne, okrętowa instalacja grzewcza.

Article history

Received: $\quad 08.02 .2019$

Reviewed: 20.03.2019

Revised: $\quad 22.04 .2019$

Accepted: 25.04 .2019 